\title{
ACCESORY AND ECTOPIC LIVER LOBE AT SAME PATIENT: CASE REPORT
}

\author{
Vasin Dragan, ${ }^{1}$ Doklestić Krstina, ${ }^{2}$ Stojadinović Milica, ${ }^{1}$ Filipović Aleksandar, \\ Kovač Jelena, ${ }^{1}$ Mašulović Dragan ${ }^{1}$ \\ ${ }^{1}$ Center for radiology and MRI, Clinical center of Serbia, Belgrade, Serbia \\ ${ }^{2}$ Clinic for emergency surgery, Clinical center of Serbia, Belgrade, Serbia
}

Primljen/Received 27. 05. 2019. god.

Abstract: Introduction: Accessory liver lobes (ALL) are defined as supranumerary liver lobes, composed of normal liver parenchyma in continuity with the liver, in contrast to ectopic liver lobes (ELL) that have no anatomical continuity with the normal liver. Case report: In this article we report on a rare radiological diagnosis of an synchronous accessory and ectopic liver lobe using ultrasonography (US) and computed tomography (CT). A 59-year-old female with no symptoms was admitted to our hospital due to preventive exam. Abdominal ultrasonography revealed a high echoic $6 \mathrm{~cm}$ x 5 $\mathrm{cm}$ soft tissue area in right anterior subhepatic space with distinct margins, a uniform echo and blood flow and was suspected to be abdominal tumor. An enhanced abdominal computed tomography (CT) showed the irregular $65 \mathrm{~mm} \times 48 \mathrm{~mm} \times 32 \mathrm{~mm}$ mass in the right hypochondrium below IV and V liver segment with clear margins, a uniform density, texture and contrast enhancement as normal liver tissue. In same patient CT also showed small $16 \mathrm{~mm} \times 12 \mathrm{~mm}$ mass in posterior mediastinum in right retrocrural space so diagnosis of accessory and ectopic liver lobe was confirmed. An accessory liver lobe is adjacent and attached to the liver by its own mesentery, while an ectopic liver lobe is one that is completely detached from the normal liver parenchyma. Conclusion: Ultrasound can show mass in the abdomen, which is most commonly in the subhepatic area, but very rarely can initially diagnose ALL or ELL due to different echogenicity of the liver parenchyma in different acoustic windows. In the case of an atypical CT presentation, an MR examination of the abdomen is indicated but it is very rarely. Fast and accurate radiological diagnosis of ALL and ELL is important in the prevention of unnecessary invasive diagnostic procedures such as laparotomy and thoracotomy which are needed only in cases of complications.
Prihvaćen/Accepted 20. 07. 2019. god.

Key words: ultrasound, CT, accesory, ectopic, liver.

\section{INTRODUCTION}

Accessory liver lobes (ALL) are defined as supernumerary liverlobes, composed of normal liver parenchyma in continuity with the liver, in contrast to ectopic liver lobes (ELL) without anatomical continuity with the normal liver (1). ALL and ELL were considered as a rare development anomaly. Most cases with an ALL are asymptomatic, and usually accidentally find on cross-sectional imaging, laparotomy or autopsy (2). Although, in rare cases, it can cause abdominal pain and liver dysfunction. It is presented a rare radiological case of synchronous accessory and ectopic liver lobe, using ultrasonography (US) and computed tomography (CT).

\section{CASE PRESENTATION}

A 59-year-old female with no symptoms was admitted to our hospital for routine exam. She had no relevant past medical or surgical history. The abdomen was soft, with no palpable masses. Abdominal ultrasonography revealed a high echoic $6 \mathrm{~cm} \times 5 \mathrm{~cm}$ soft tissue area in right anterior subhepatic space, with distinct margins, and uniform echo and blood flow. It was suspicious of the presence of abdominal tumor (Figure 1a-b). The laboratory data showed normal hepatic function, with anaspartate transaminase (AST) level of 21 $\mathrm{U} / \mathrm{L}(0-40)$, alanine transaminase (ALT) level of $26 \mathrm{U} / \mathrm{L}$ (0-41), gamma-glutamyl transferase (GGT) level of 20 $\mathrm{U} / \mathrm{L}(0-30)$ and bilirubin level $0.5 \mathrm{mg} / \mathrm{dl}(0.2-1 \mathrm{mg} / \mathrm{dl})$.

An enhanced abdominal computed tomography (CT) showed irregular $65 \mathrm{~mm}$ x $48 \mathrm{~mm}$ x $32 \mathrm{~mm}$ mass in the right hypochondrium, below segments IV and $\mathrm{V}$ of the liver, with clear margins and uniform density, 


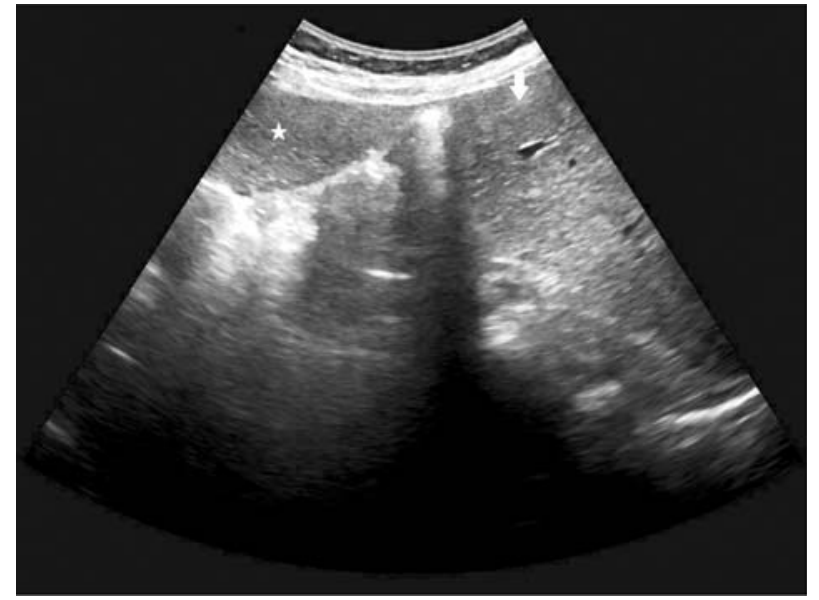

Figure 1a. Abdominal ultrasonography-sagital scan: high echoic soft tissue area (star) in subhepatic space with distinct margins and uniform echo with suspected connection to the right liver lobe (arrow)

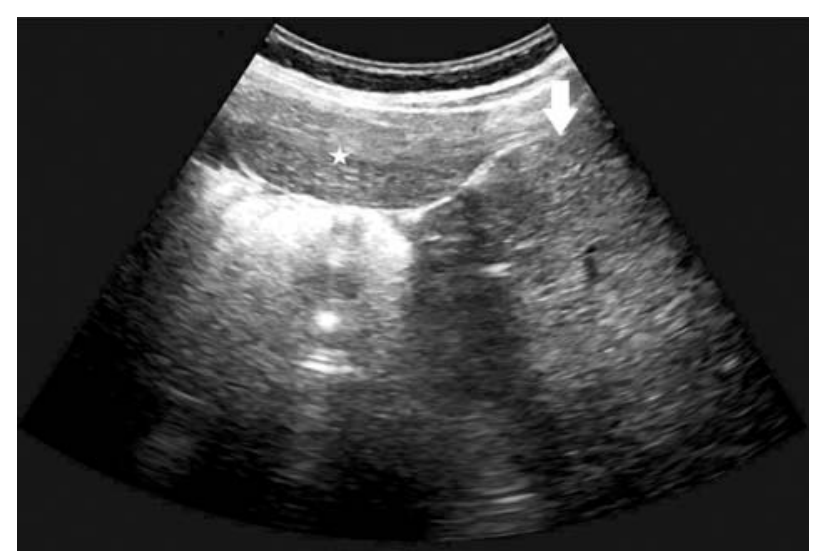

Figure 1b. Abdominal ultrasonography - oblique scan: soft tissue area (star) in subhepatic space with suspected connection to the right liver lobe (arrow)

texture and contrast enhancement as normal liver tissue (Figure 2a-b). Mass was attached to the caudal part of segment $\mathrm{V}$ of the liver by a thin stalk of liver tissue, that contained a vascular pedicle. After CT exam abdominal ultrasonography was performed again, and color-doppler signal of the hepatic vein (Figure 3) was seen at the level of the stalk. These findings suggest the diagnosis of ALL. CT also showed small $16 \mathrm{~mm} \times 12$ $\mathrm{mm}$ mass in the right retrocrural space of posterior mediastinum (Figure 4a-b), with the same CT features as liver tissue but without tissue or vascular connection to the liver. That helped to confirm diagnosis of ELL.

\section{DISCUSSION}

An accessory liver lobe is a rare congenital development anomaly that is usually asymptomatic and mostly detected accidentally at laparotomy (4). It occurs from an error in the development of the endodermal caudal foregut, during the third gestational week,

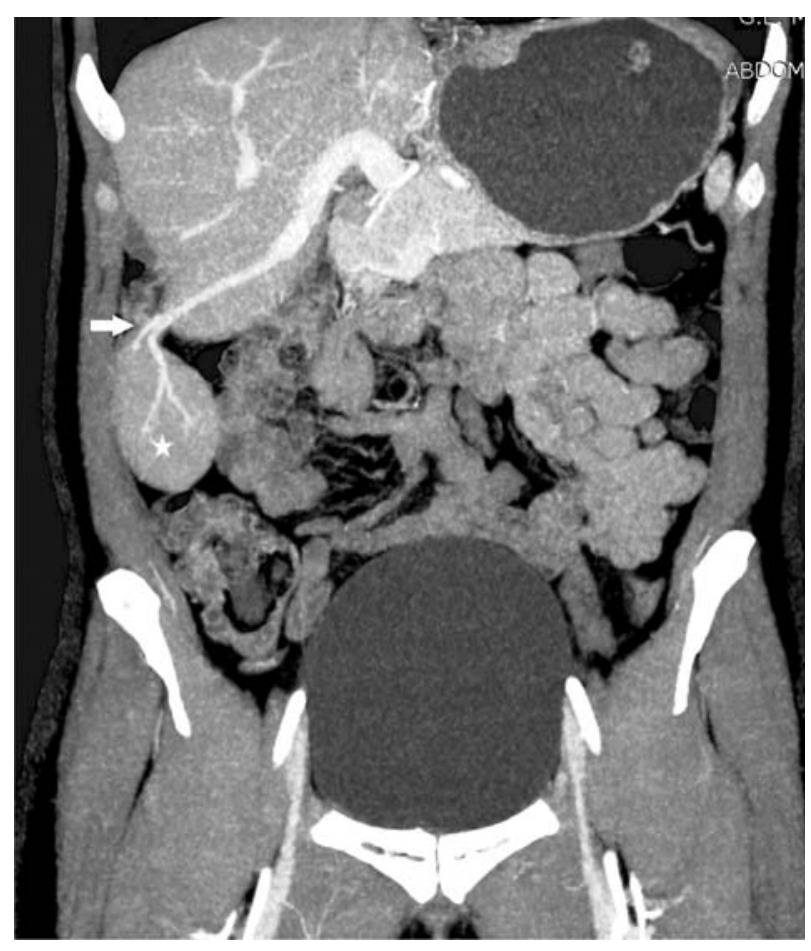

Figure 2a. Contrast enhanced abdominal CT-multiplanar coronal reconstruction: solid mass (star) in the right hypochondrium below $I V$ and $V$ liver segment with clear margins, a uniform density, texture and contrast enhancement as normal liver tissue, attached to the caudal pole of liver segment $V$ by a thin stalk of liver tissue that contained a vascular pedicle (arrow) CT feature of accessory liver lobe

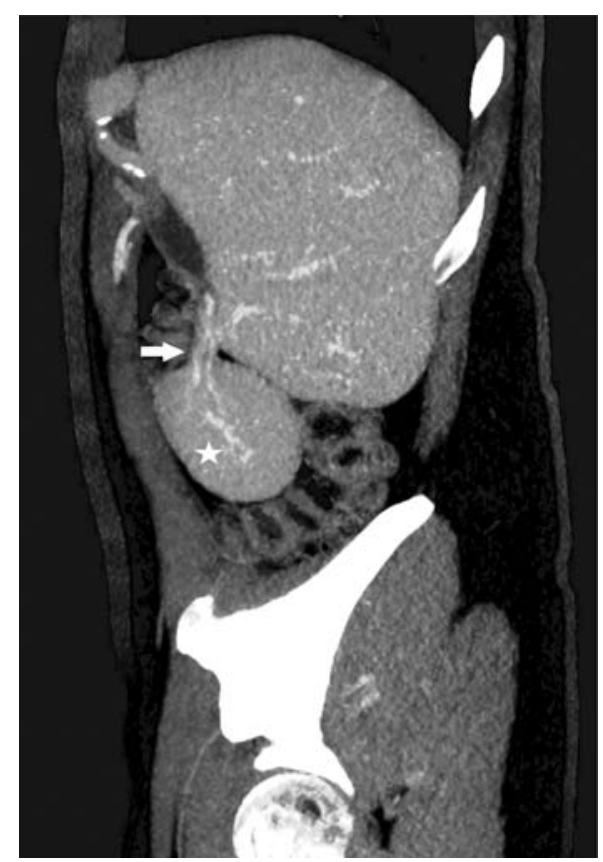

Figure 2b. Contrast enhanced abdominal CT-sagital reconstruction: solid mass (star) in the right hypochondrium below IV and Vliver segment attached to the caudal pole of liver segment $V$ by a thin stalk of liver tissue that contained a vascular pedicle (arrow) 


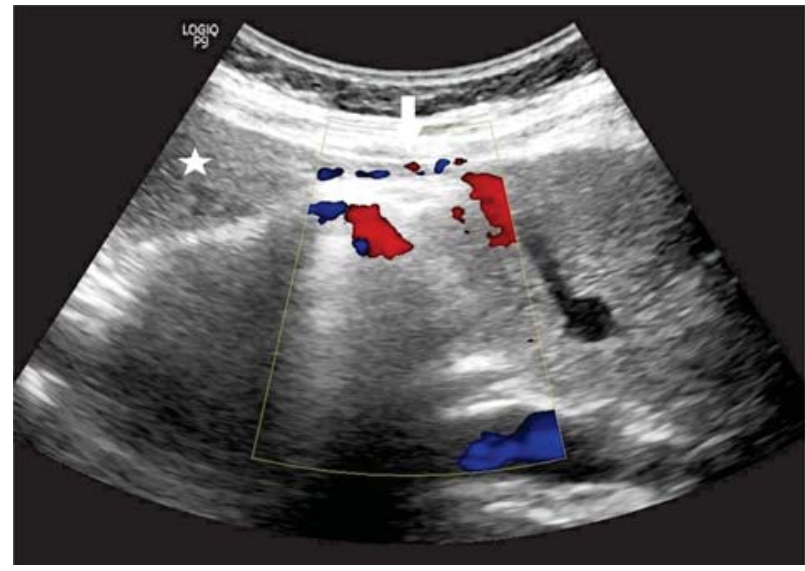

Figure 3. Abdominal color-doppler ultrasonographysagital scan: soft tissue area (star) in subhepatic space with vascular connection (star) to the right liver lobe

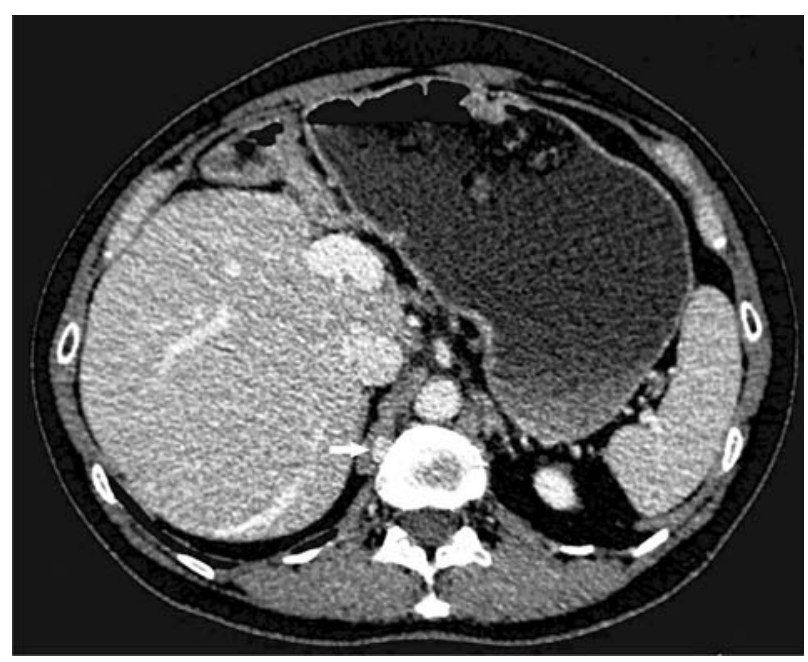

Figure 4a. Contrast enhanced abdominal CT - axial scan: small mass (arrow) in posterior mediastinum in right retrocrural space, same CT characteristics as liver tissue but without tissue or vascular connection to the liver-CT feature of ectopic liver lobe

and segmentation of the hepatic bud (5). An accessory liver lobe is adjacent and attached to the liver by its own mesentery, while an ectopic liver lobe is one that is completely detached from the normal liver parenchyma (6). Four types of accessory liver has been described in the literature: big accessory hepatic lobe (> $30 \mathrm{~g})$, small accessory hepatic lobe $(<30 \mathrm{~g})$, ectopic lobe with no liver connection, and microscopic accessory lobe in the gallbladder wall (3).

The development of new imaging methods such as US, CT and MR detect an increasing number of ALLs during examination performed for unrelated cause.

Ultrasonography is the mostly used initial imaging method in the abdominal pathology. Ultrasound can show mass in the abdomen, which is most commonly located in the subhepatic space, but rarely can initially confirm ALL or ELL, due to different echogenicity of

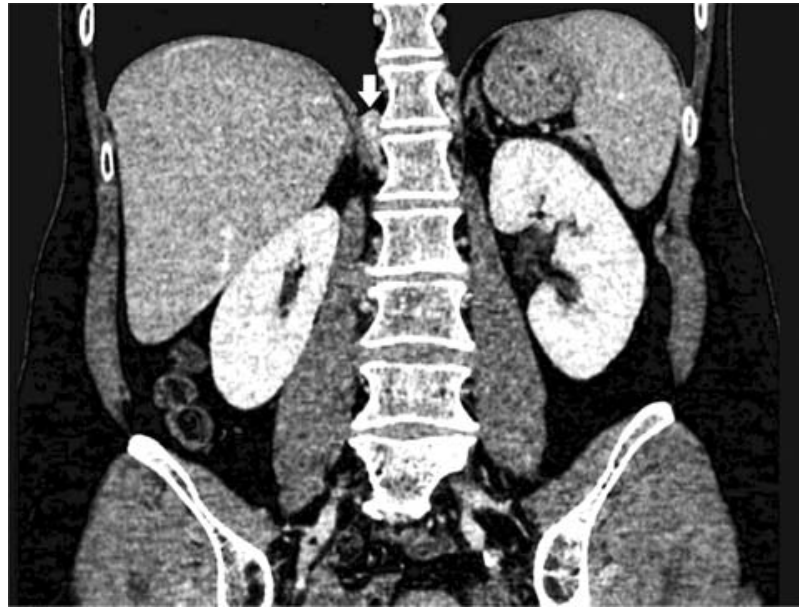

Figure $4 \boldsymbol{b}$. Contrast enhanced abdominal CT-multiplanar coronal reconstruction: small mass in right retrocrural space, same CT characteristics as liver tissue but without tissue or vascular connection to the liverCT feature of ectopic liver lobe

the liver parenchyma in different acoustic windows. In some cases, the color doppler scan can be useful in detection a blood supply within the liver parenchyma, but it can not exclude pedunculated liver tumors. Therefore, the ultrasound examination could raise suspicion of the presence of abdominal tumor, but CT scan is necessary as a next diagnostic step, to confirm diagnosis.

CT findings of ALL are following: (i) significant part of the accessory lobe has the same density or signal as normal liver tissue; (ii) the ALL have distinct and smooth margins, with complete demarcation; (iii) the ALL is connected with normal liver tissue over a stalk of tissue or base; (iv) vein presentation in ALL was apparent during enhanced CT scanning (7). In the rare case of atypical CT presentation, abdominal MR image is indicated. Ectopic ALL within the thorax may be misdiagnosed for pulmonary, pleural or diaphragmatic tumor, depending on its location (8).

Asymptomatic patients with ALL and ELL accidentally discovered, do not require any treatment. Complications related to ALL includes torsion, infarction, hemorrhage and fracture of the accessory lobe, and may require urgent laparotomy (2).

\section{CONCLUSION}

Prompt and accurate radiological diagnosis of ALL and ELL is important in the prevention of unnecessary invasive diagnostic procedures such as laparotomy or thoracotomy, which are needed only in cases of complications.
Abbreviations
MR - magnetic resonance
ALL - Accessory liver lobes 
ELL - ectopic liver lobes

US - ultrasonography

CT - computed tomography

Acknowledgment: None

Conflict of Interests: The authors declare that there are no conflicts of interest related to this article.
Funding: This research did not receive any specific grant from funding agencies in the public, commercial, or not-for-profit sectors.

\section{Licensing}

This work is licensed under a Creative Commons Attribution 4.0 International (CC BY 4.0) License.

\title{
Sažetak
}

\section{AKCESORNI I EKTOPIČNI LOBUS JETRE KOD ISTOG PACIJENTA: PRIKAZ SLUČAJA}

\author{
Vasin Dragan, ${ }^{1}$ Doklestić Krstina, ${ }^{2}$ Stojadinović Milica, ${ }^{1}$ Filipović Aleksandar, \\ Kovač Jelena, ${ }^{1}$ Mašulović Dragan ${ }^{1}$ \\ ${ }^{1}$ Center for radiology and MRI, Clinical center of Serbia, Belgrade, Serbia \\ ${ }^{2}$ Clinic for emergency surgery, Clinical center of Serbia, Belgrade, Serbia
}

Uvod: Akcesorni lobusi jetre (ALL) se definišu kao prekobrojni lobusi jetre, koji su sastavljeni od normalnog parenhima jetre, u odnosu na ektopične lobuse jetre (ELL), koji nemaju anatomski kontinuitet sa normalnom jetrom. Prikaz slučaja: U ovom radu je prikazan slučaj retke radiološke dijagnoze sinhronog postojanja akcesornog i ektopičnog jetrinog lobusa koristeći ultrazvuk (UZ) i kompjuterizovanu tomografiju (CT). 59-godišnja pacijentkinja bez simptoma je bila primljena u našu bolnicu, radi preventivnog pregleda. Ultrazvukom abdomena otkriveno je izraženo ehogeno polje mekog tkiva $6 \times 5 \mathrm{~cm} \mathrm{u}$ desnom prednjem subhepatičnom prostoru sa jasnim marginama. S obzirom na postojanje kolor-dopler signala postavljena je sumnja na tumorsku promenu u abdomenu. Kompjuterizovana tomografija (CT) nakon intravenske aplikacije kontrasta je pokazala mekotkivnu promenu dijametara $65 \mathrm{~mm} \mathrm{x}$

\section{REFERENCES}

1. Morris Jr MW, Helling TS, Creswell LL, Jordan B, Mitchell EM. Ectopic liver masquerading as a floating intracaval mass. J Vasc Surg. 2012; 55(6): 1759-61.

2. Kapoor A, Harshavardhan KR, Mutnuru PC, Narayanan R. Accesory hepatic lobe - A ,not so rare“ entity. Int. J. Anat, Surg and Radiol. 2017; 6(2): 26-30.

3. M. Massaro, M. P. Valencia, M. Guzman, Mejja J. Accessory hepatic lobe mimicking an intra-abdominal tumor. J. Comput. Assist. Tomogr. 2007; 31 (4): 572-3.

4. Ladurner R, Brandacher G, Mark W, Iannetti C, Lottersberger $\mathrm{C}$, Steurer W, et al. Complete hepatic ischemia due to tor-

\section{Correspondence to/Autor za korespondenciju}

Dragan Vasin, MD

Center for radiology and MRI, Clinical center of Serbia Street Vojvode Micka 1i, Belgrade, Serbia

email: draganvasin@gmail.com
$48 \mathrm{~mm}$ x $32 \mathrm{~mm}$ u desnom hipohondrijumu ispod IV i V segmenta jetre, oštrih kontura, uniformnih denziteta, teksture i kontrastne opacifikacije koja bi odgovarala normalnom tkivu jetre. Kod istog pacijenta CT je pokazao malo polje $16 \mathrm{~mm}$ x $12 \mathrm{~mm}$ u posteriornom medijastinumu u desnom retrokruralnom prostoru. $\mathrm{S}$ toga je dijagnoza akcesornog i ektopičnog jetrinog lobusa bila potvrđena. Zaključak: Akcesorni režanj jetre se najčešće javlja u subhepatičnom prostoru ali se retko inicijalno dijagnostikuje iz razloga različite ehogenosti od parenhima jetre koja je posledica različitih akustičnih prozora. Brza i precizna radiološka dijagnoza ALL i ELL je važna u prevenciji nepotrebnih invazivnih dijagnostičkih procedura, kao što su laparotomija i torakotomija, koje su potrebne samo u komplikoovanim slučajevima.

Ključne reči: ultrazvuk, CT, akcesorni deo, ektopičnost, jetra.

sion of a large accessory liver lobe: first case to require transplantation. Transpl Int. 2005; 18(4): 467-9.

5. Carrabetta S, Piombo A, PodestB R, Auriati L. Torsion and infarction of accessory liver lobe in young man. Surgery. 2009; 145(4): 448-9.

6. Jambhekar K, Pandey K, Kaushik P, Shah HP. Intermittent torsion of accessory hepatic lobe: An unusual cause of recurrent right upper quadrant pain. Indian J Radiol Imaging. 2010; 20(2): 135-7.

7. Wang C, Cheng L, Zhang Z, Xie T, Ding H, Deng Q et al. Accessory lobes of the liver: A report of 3 cases and review of the literature. Intractable Rare Dis Res. 2012; 1(2): 86-91.

8. Wang Y, Junlin L, Zhang WG, Chen JH, He Y, Chen JM. Accessory lobe of right liver mimicking a pulmonary tumor in an adult male. Ann Thorac Surg. 2010; 89(2): e9-10. 